GRASAS Y ACEITES 65 (4)

October-December 2014, e053

ISSN-L: 0017-3495

doi: http://dx.doi.org/10.3989/gya.0585141

\title{
Lipase-catalyzed interesterification of egg-yolk phosphatidylcholine and plant oils
}

\author{
A. Chojnacka ${ }^{\bowtie}$, W. Gładkowski, G. Kiełbowicz, A. Gliszczyńska, N. Niezgoda and C. Wawrzeńczyk \\ Department of Chemistry, Wrocław University of Environmental and Life Sciences, Norwida 25, Wroclaw 50-375, Poland \\ ${ }^{\square}$ Corresponding author: jeanna@wp.pl
}

Submitted: 30 May 2014; Accepted: 03 August 2014

SUMMARY: The incorporation of polyunsaturated fatty acids into the $s n-1$ position of egg-yolk phosphatidylcholine (PC) in the process of lipase-catalyzed interesterification was investigated. For this purpose plant oils containing these acids in the triacylglycerol (TAG) form were used as acyl donors and three commercially available immobilized lipases were examined as biocatalysts. In all the experiments the best results were obtained using Novozym 435. After $72 \mathrm{~h}$ of the reaction of PC with linseed oil the maximum incorporation of $\alpha$-linolenic acid into PC was $34 \%$. The result of this reaction was also a reduction in the $n-6 / n-3$ ratio in egg-yolk PC from 24.5 to 0.7 . The highest incorporation $n$-6 PUFAs into PC were obtained with evening primrose oil as the acyl donor, and in this case, $50.7 \%$ of $n$-6 PUFA as the sum of linoleic and $\gamma$-linolenic was achieved. The highest content of $\gamma$-linolenic acid in modified PC (7.3\%) was achieved in the reaction of PC with borage oil.

KEYWORDS: Egg-yolk phosphatidylcholine; Interesterification; Lipase; Plant oil; Polyunsaturated fatty acids; Structured phospholipids

RESUMEN: Interesterificación de fosfatidilcolina de yema de huevo y aceites vegetales catalizada por lipasas. Se ha investigado la incorporación de ácidos grasos poliinsaturados en la posición sn-1 de fosfatidilcolina de yema de huevo (PC) en el proceso de interesterificación catalizado por lipasas. Para lograr este propósito, fueron examinados aceites vegetales que contienen estos ácidos en la forma de triacilgliceroles (TAG) como donadores de acilo y tres lipasas inmovilizadas disponibles comercialmente. En todos los experimentos los mejores resultados se obtuvieron para Novozym 435. La incorporación máxima de ácido $\alpha$-linolénico en PC fue del 34\% después de $72 \mathrm{~h}$ de la reacción de PC con aceite de linaza. El resultado de esta reacción fue también la reducción de la relación de n-6/n-3 en PC de yema de huevo de 24.5 a 0.7. La incorporación más alta de n-6 PUFAs en PC se logró para el aceite de onagra como donador de acilo, en este caso se alcanzó el 50.7\% de n-6 PUFA, como suma de los ácidos linoleico y $\gamma$-linolénico. El mayor contenido de ácido $\gamma$-linolénico en PC modificado (7.3\%) se logró en la reacción de PC con aceite de borraja.

PALABRAS CLAVE: Aceite vegetal; Ácidos grasos poliinsaturados; Fosfatidilcolina de yema de huevo; Fosfolípidos estructurados; Interesterificación; Lipasa

Citation/Cómo citar este artículo: Chojnacka A, Gładkowski W, Kiełbowicz G, Gliszczyńska A, Niezgoda N, Wawrzeńczyk C. 2014. Lipase-catalyzed interesterification of egg-yolk phosphatidylcholine and plant oils. Grasas Aceites 65 (4): e053. doi: http://dx.doi.org/10.3989/gya.0585141.

Copyright: (C) 2014 CSIC. This is an open-access article distributed under the terms of the Creative Commons Attribution-Non Commercial (by-nc) Spain 3.0 Licence. 


\section{INTRODUCTION}

Polyunsaturated fatty acids (PUFA) of the $n-3$ series as well as those of the $n-6$ series are known to be essential nutrients in the human diet. Linoleic acid (LA, 18:2, $n$-6) and $\alpha$-linolenic acid (ALA, 18:3, $n$-3) as essential fatty acids (EFA) are very important for maintaining bio-functions in mammals (Nagao and Yanagita, 2008; Vessby, 2003). Because of the lack of adequate desaturases human systems do not synthesize linoleic acid and $\alpha$-linolenic acid. Once obtained from the diet, ALA can be further metabolized by $\Delta-6$ desaturation, elongation and $\Delta-5$ desaturation to eicosapentaenoic acid (EPA, 20:5, $n$-3) and docosahexaenoic acid (DHA, 22:6, $n-3$ ), while LA is converted by the same enzymatic route to $\gamma$-linolenic acid (GLA, 18:2, n-6) and arachidonic acid (ARA, 20:4, $n-6)$.

It has been reported that the consumption of $n-3$ PUFA, especially ALA and DHA, correlates with a reduced risk of cancer and cardiovascular diseases and prevents hypertension (Berry and Hirsch, 1986; Bigger and El-Sherif, 2001; Holub and Holub, 2004; Kris-Etherton et al., 2004). DHA is a crucial factor in the normal development of brain and retina (Uauy and Dangour, 2006). ARA and EPA are the parent compounds for the production of eicosanoids whereas skin improving effects have been ascribed mainly to LA and GLA (Muggli, 2005; van Gool et al., 2004).

Phospholipids (PL) are very interesting natural compounds for many reasons. They are the main structural components of biological membranes and they take a part in cell signaling mechanisms (Dowhan, 1997). In addition, they are found in several industrial applications, e.g. as emulsifiers in pharmaceutical and food products and components of liposomes for cosmetics and drug delivery (Gabizon et al., 1997; Schneider, 2001).

Some oilseeds (e.g. soybean) and egg-yolk are particularly rich in phospholipids. The egg-yolk lecithin comprises $78 \%$ phosphatidylcholine (PC), 18\% phosphatidylethanolamine (PE) and $2 \%$ cholesterol. The major fatty acids in egg-yolk PC are: palmitic $(16: 0 ; 35 \%)$, stearic $(18: 0 ; 13.4 \%)$, oleic $(18: 1 ; 30.4 \%)$, linoleic $(18: 2 ; 18 \%)$ and arachidonic $(20: 4 ; 3.2 \%)$ (Palacios and Wang, 1995). It should be emphasized that the fatty acid composition of egg-yolk lipids is strongly influenced by modifications in the hens' diet (Cobos et al., 1995). Studies showed that when hen feed was supplemented with some plant or fish oils the enrichment of egg-yolk lipids (especially PC) with $n-3$ polyunsaturated fatty acids (PUFA) was observed (Gładkowski et al., 2011; Lewis et al., 2000; Fraeye et al., 2012). Nevertheless, their total content in yolk fatty acid composition did not exceed $15 \%$.

Phospholipids as the source of essential fatty acids may be an efficient dietary vehicle to deliver these valuable components. Considerable efforts are being made to incorporate health-promoting fatty acids from the $n-3$ or $n-6$ family into PL in the production of food or cosmetic additives. Incorporating DHA and EPA into PL was reported by several authors (Haraldsson and Thorarenson, 1999; Mutua and Akoh, 1993; Kim et al., 2010; Garcia et al., 2008). Reports on the incorporation of LA, ALA or GLA especially into PC isolated from egg-yolk are limited (Ghosh and Bhattacharyya, 1997; Hara et al., 2002).

The use of lipases and phospholipases allows for the specific removal or replacement of the acyl chains at position $s n-1$ or $s n-2$ of PL via hydrolysis and reesterification or through direct interesterification using different acyl donors (Haraldsson and Thorarenson, 1999; Mutua and Akoh, 1993; Lyberg et al., 2005; Park et al., 2000; Baeza-Jimenez et al., 2012; Kim et al., 2007).

The results of our studies on the incorporation of ALA into egg-yolk PC in the $s n-1$ and $s n-2$ position have been reported previously (Chojnacka et al., 2009). Because of the fact that natural plant oils are a rich source of PUFAs in the form of triacylglycerols (TAG), in these studies we looked into the possibilities of producing ALA-, LA- or GLAenriched PC in the lipase-catalyzed direct interesterification of egg-yolk PC with plant oils. During this reaction the acids from the $s n-1$ position of $\mathrm{PC}$ are exchanged to the acids in the $s n-1$ and $s n-3$ positions of TAGs from oils (Scheme 1). No data about the application of edible oils as reagents in the enzymatic incorporation of PUFA into phospholipids have been reported as yet.

\section{MATERIALS AND METHODS}

\subsection{Materials}

Lohmann Brown hens' eggs were a gift from the Tronina factory. Linseed oil, sunflower oil, safflower oil, borage oil and evening primrose oil were purchased from the Oleofarm Co., Poland. Lipozyme TL IM (a silica granulated Thermomyces lanuginosus. lipase preparation, $250 \mathrm{U} / \mathrm{g}$ ), was a gift from the Novozymes A/S (Bagsvaerd, Denmark). Lipase B from Candida antarctica (synonym: Novozym 435>5,000 $\mathrm{U} / \mathrm{g}$ ), immobilized in a macroporous acrylic resin and lipase from Mucor miehei (Lipozyme ${ }^{\circledR}>30 \mathrm{U} / \mathrm{g}$ ), immobilized in an anion-exchange resin were purchased from Sigma-Aldrich. Methanol (pure p.a.), hexane (pure p.a.), acetone (pure p.a.) and chloroform (pure p.a.) as well as $\mathrm{NaOH}, \mathrm{NaCl}$ and anhydrous $\mathrm{MgSO}_{4}$ were purchased from Chempur ${ }^{\circledR}$ (Poland, Piekary Śląskie). HPLC grade solvents: 2-propanol, $n$-hexane (used also for the enzymatic reaction), and a boron trifluoride methanol complex solution $(13-15 \%$ $\left.\mathrm{BF}_{3} \times \mathrm{MeOH}\right)$ were purchased from Sigma-Aldrich. Boron trifluoride ethyl etherate $\left(48 \% \mathrm{BF}_{3} / \mathrm{Et}_{2} \mathrm{O}\right)$ was bought from Fluka. Ethanol $(95 \%)$ was purchased from POCh (Poland, Gliwice). The silica gel 


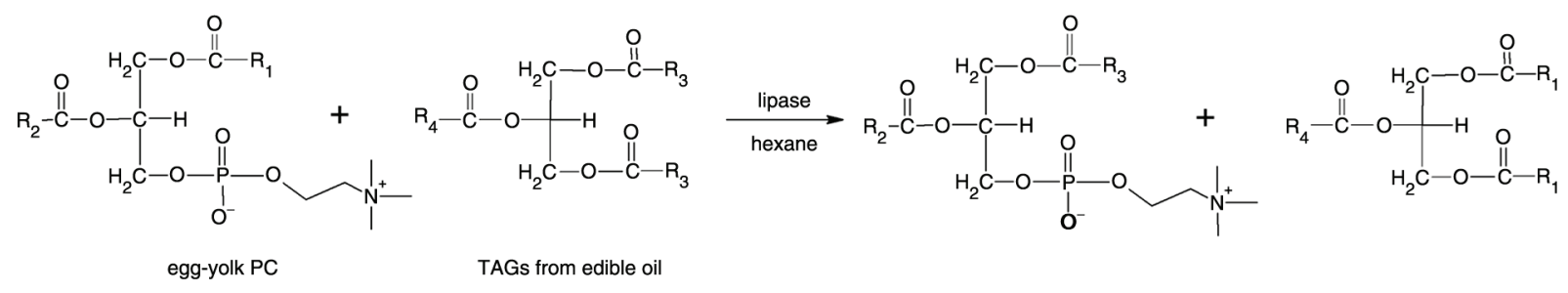

SCHEME 1.

(Kieselgel 60, 230-400 mesh) used in the column chromatography and silica gel-coated aluminium plates (Kieselgel $60 \mathrm{~F}_{254}, 0.2 \mathrm{~mm}$ ) used in thin layer chromatography (TLC) were purchased from Merck.

\subsection{Isolation of $P C$ from egg-yolk}

A pure phospholipid fraction $(1.35 \mathrm{~g})$ was isolated from $20 \mathrm{~g}$ of the fresh egg-yolk by the extraction with ethanol and precipitation of crude PL-fraction with cold acetone (Gładkowski et al., 2012). The pure PC (0.9 g) was separated from this fraction by silica gel column chromatography (chloroform/methanol/water, 65:25:4, v/v/v).

\subsection{The lipase-catalyzed interesterification of PC with plant oils}

The reactions were carried out using three different lipases, in $\mathrm{N}_{2}$ atmosphere, at $55^{\circ} \mathrm{C}$. They were initiated by adding $270 \mathrm{mg}$ of enzyme $(20 \% \mathrm{w} / \mathrm{w}$ of total substrates) to the mixture containing egg-yolk PC (0.52 mmol, $400 \mathrm{mg})$ and plant oil $(1.05 \mathrm{mmol})$ in $5 \mathrm{~mL}$ of hexane. The reaction mixture was agitated in a magnetic stirrer at $300 \mathrm{rpm}$. All trials were carried out in duplicate. The reactions were stopped at the selected time interval by enzyme filtration and modified PC and LPC were separated from the mixtures by column chromatography and then converted to fatty acid methyl esters (FAME).

\subsection{Analysis}

High performanceliquid chromatography (HPLC) analysis was carried out using a DIONEX UltiMate 3000 LC system equipped with a CORONA CAD detector (ESA Biosciences, Chelmsford, MA). A Waters Spherisorb S5W column $(150 \times 4.6 \mathrm{~mm})$ was used for analysis. The HPLC gradient program (flow rate $1 \mathrm{~mL} \cdot \mathrm{min}^{-1}$ ) was set as follows: at $0 \mathrm{~min} 59 / 40 / 1(\% \mathrm{~A} / \% \mathrm{~B} / \% \mathrm{C})$, at $6 \mathrm{~min} 52 / 40 / 8$, at $21 \mathrm{~min} 59 / 40 / 1$, then held for $5 \mathrm{~min}(\mathrm{~A} / \mathrm{B} / \mathrm{C}=$ water/ hexane/2-propanol).

The progress of enzymatic reactions and purity of the products were monitored by TLC on silica gel-coated aluminium plates (chloform/methanol/ water, 65:25:4, v/v/v). The purity of the modified phosphatidylcholine was determined by HPLC after prior purification by means of column chromatography on silica gel using the same eluent as mentioned above.

\subsubsection{Preparation and analysis of FAME}

Samples $(50 \mathrm{mg}$ ) were dissolved in $2 \mathrm{~mL}$ of a $0.5 \mathrm{M}$ methanolic $\mathrm{NaOH}$ solution. After heating for 2 minutes under reflux $1 \mathrm{~mL}$ of $\mathrm{BF}_{3} \times \mathrm{MeOH}$ complex solution was added and the mixtures were heated again for 3 minutes. After cooling the mixture was extracted with $1 \mathrm{~mL}$ of hexane and the organic layer was washed with a saturated $\mathrm{NaCl}$ solution. Hexane extracts were dried over anhydrous magnesium sulphate $\left(\mathrm{MgSO}_{4}\right)$ and analyzed directly by GC using a 70\% cyanopropyl polysilphenylene-siloxane column (TR FAME, $30 \mathrm{~m} \times 0.25 \mathrm{~mm} \times 0.25 \mu \mathrm{m}$ ) and FID detector. The temperature parameters were as follows: injector $250{ }^{\circ} \mathrm{C}$, detector $280{ }^{\circ} \mathrm{C}$, column: $160{ }^{\circ} \mathrm{C}$ (held $3 \mathrm{~min}$ ), $160-220^{\circ} \mathrm{C}\left(\right.$ rate $5^{\circ} \mathrm{C} \cdot \mathrm{min}^{-1}$ ), $220-260{ }^{\circ} \mathrm{C}$ (rate $30^{\circ} \mathrm{C} \cdot \mathrm{min}^{-1}$ ), $260^{\circ} \mathrm{C}$ (held $3 \mathrm{~min}$ ). Total time: $19.33 \mathrm{~min}$. FAs were identified by comparing the retention times of their methyl esters with a standard FAMEs mixture (Supelco 37 FAME Mix) purchased from Sigma-Aldrich.

\subsubsection{Positional analysis of fatty acids in native and modified $P C$}

The procedure described by Kiełbowicz et al. (2012) was applied:

Position $s n-1$.Ethanol $(95 \%, 2 \mathrm{~mL})$ and Lipozyme ${ }^{\circledR}$ $(0.4 \mathrm{~g})$ were added to PC $(0.05 \mathrm{~g})$ and the mixture was shaken vigorously for $8 \mathrm{~h}$. The enzyme was filtered off, ethanol was evaporated and the remaining material was suspended in $2 \mathrm{~mL}$ of water and vigorously mixed using a vortex mixer. The obtained suspension was transferred to a $15 \mathrm{~mL}$ vial and $3 \mathrm{~mL}$ of hexane were added to extract free fatty acids (FFA) and fatty acid ethyl esters (FAEE) released from the $s n-1$ position of PC. The two phases obtained after extraction were separated. The water fraction containing 2-acyl LPC was left for further analysis (see "position sn-2"). The solvent (from hexane extract) was evaporated and $2 \mathrm{~mL}$ of anhydrous ethanol and $1 \mathrm{~mL}$ of $48 \% \mathrm{BF}_{3} / \mathrm{Et}_{2} \mathrm{O}$ were added. The mixture was refluxed for $3 \mathrm{~min}$ to complete the conversion of FFA into FAEE. After cooling the mixture was 
extracted with $1 \mathrm{~mL}$ of hexane and the organic layer was washed with a saturated $\mathrm{NaCl}$ solution, dried over anhydrous $\mathrm{MgSO}_{4}$ and FAEE were analyzed directly by gas chromatography to give the composition of FA in the $s n-1$ position of PC. The temperature parameters during the GC analysis were the same as those for the analysis of FAME. The FAs were identified by comparing the retention times of their ethyl esters with a standard FAEEs mixture previously prepared (Kiełbowicz et al., 2012).

Position $s n-2$. The water fraction with 2-acyl LPC was concentrated at $60{ }^{\circ} \mathrm{C}$ in vacuo and the remaining material was dissolved in $0.5 \mathrm{~mL}$ of hexane and transferred to a centrifuge bottle where cold acetone $\left(-20{ }^{\circ} \mathrm{C}, 10 \mathrm{~mL}\right)$ was added to precipitate 2-acyl LPC. The precipitate was carefully washed 3 times with $10 \mathrm{~mL}$ portions of cold acetone and the solvent was removed by decantation each time. The mixture was then centrifuged $(10,000 g, 1 \mathrm{~min})$. The supernatant was removed and $10 \mathrm{mg}$ of sample of pure 2-acyl LPC were dissolved in $2 \mathrm{~mL}$ of a $0.5 \mathrm{M}$ ethanolic $\mathrm{NaOH}$ solution and heated under reflux for $2 \mathrm{~min}$. Afterwards, $1 \mathrm{~mL}$ of $48 \% \mathrm{BF}_{3} / \mathrm{Et}_{2} \mathrm{O}$ was added to convert the fatty acid from the $s n$-2-position to FAEE. Further treatment of samples before GC analysis was the same as described for the analysis of FA from the $s n-1$ position.

\section{RESULTS AND DISCUSSION}

Lipase-catalyzed egg-yolk phosphatidylcholineplant triacylglycerol interchange reaction (Scheme 1) was applied to modify PC to increase its nutritional qualities.

The material for our studies was PC isolated from Lohmann Brown hens eggs. It was previously subjected to FA analysis and the results (Table 1) showed that palmitic (16:0) and oleic (18:1) were the predominating ones. The first one as well as stearic acid (18:0) are located in the $s n-1$ position whereas the oleic acid is the major acid in the $s n-2$ position. The $s n-2$ position is also occupied by unsaturated acids from the $n-6$ family (LA and ARA) (Table 2). The presence of small quantities of DHA and EPA can be observed as the result of feeding the hens with feed supplemented with dietary sources of $n-3$ PUFAs such as flaxseed and fish oils. The studies revealed that in this way EPA, DPA and DHA can be incorporated only at the sn-2 position (Gładkowski et al., 2011; Gładkowski et al., 2014) whereas ALA is not accumulated in the PL fraction at all (Aymond and van Elswyk, 1995).

Unsaturated fatty acids present at the $s n-2$ position can be released in humans only by phospholipase $A_{2}$. In order to make them more bioavailable we decided to apply 1,3-regioselective lipases to the modification of egg-yolk PC. The introduction of desired fatty acids in the $s n-1$ position will make them more susceptible to the lipases present in our digestive track.

As the acyl donors we chose commercial plant oils in which ALA, LA and GLA are present in the form of triacylglycerols. The fatty acid composition of TAGs from these oils (Table 1) indicates that the content of linoleic acid in safflower, sunflower and evening primrose oils is $70-75 \%$ and linseed oil is the richest source of $\alpha$-linolenic acid (58.5\%). Additionally, evening primrose oil and borage oil contain $\gamma$-linolenic acid (10.4 and 20.7\%, respectively). A stereospecific analysis in edible plant oils showed that with some exceptions such as cocoa butter or peanut oil, unsaturated fatty acids are almost equally distributed in all positions of the glycerol skeleton (Brockerhoff and Yurkowski 1966; Christie et al., 1991).

\subsection{Interesterification of egg-yolk PC with linseed oil}

The fortification of phospholipids with ALA is especially desirable because of the metabolism pathway in which ALA is converted to EPA and DHA by the elongation and desaturation of the hydrocarbon chain. Previous studies on the preparation of ALAenriched PC were limited to the acidolysis process

TABLE 1 . The fatty acid profile of starting materials ( $\%$ according to GC) $)^{\mathrm{a}}$

\begin{tabular}{|c|c|c|c|c|c|c|}
\hline FA & Native PC & Linseed oil & Safflower oil & Sunflower oil & Evening primrose oil & Borage oil \\
\hline C16:0 & 30 & 5.4 & 7.3 & 7.9 & 6.7 & 9.9 \\
\hline C16:1 & 1.5 & - & - & - & - & - \\
\hline C18:0 & 15 & 3.3 & 2.8 & 4.9 & 2.0 & 5.7 \\
\hline C18:1 & 28 & 16.8 & 19.5 & 16.3 & 5.7 & 19.3 \\
\hline $\mathrm{C} 18: 2$ & 20 & 16.0 & 70.4 & 70.9 & 74.3 & 40.3 \\
\hline C18:3 (ALA) & - & 58.5 & - & - & - & - \\
\hline C18:3 (GLA) & - & - & - & - & 10.4 & 20.7 \\
\hline C20:4 (ARA) & 4.5 & - & - & - & 0.9 & 4.1 \\
\hline C22:6 (DHA) & 1 & - & - & - & - & - \\
\hline
\end{tabular}

\footnotetext{
${ }^{\mathrm{a}}$ Tabular entries are the average of duplicate determinations from different experimental trials.
} 
TABLE 2. Total and positional fatty acid composition (\% according to GC) of native egg-yolk PC and structured PC (SPC) obtained after 72 hours of enzymatic transesterification of egg-yolk PC with linseed oil ${ }^{\mathrm{a}}$

\begin{tabular}{|c|c|c|c|c|c|c|c|c|c|}
\hline \multirow[b]{3}{*}{ FA } & & & & \multicolumn{6}{|c|}{ SPC (linseed oil) ${ }^{b}$} \\
\hline & \multicolumn{3}{|c|}{ Native egg-yolk PC } & \multicolumn{3}{|c|}{ Novozym 435} & \multicolumn{3}{|c|}{ Lipozyme® ${ }^{\circledR}$} \\
\hline & Total & $s n-1$ & $s n-2$ & Total & $s n-1$ & $s n-2$ & Total & $s n-1$ & $s n-2$ \\
\hline C16:0 & 30 & 63 & 1 & 8 & 8 & 2 & 11 & 28 & 1 \\
\hline C16:1 & 1.5 & 2 & 1 & 1 & 3 & - & 1 & 1 & - \\
\hline C18:0 & 15 & 29 & - & 3 & 3 & 2 & 9 & 13 & - \\
\hline C18:1 & 28 & 5 & 47 & 28 & 9 & 45 & 31 & 10 & 51 \\
\hline C18:2 (LA) & 20 & 1 & 43 & 22 & 8 & 36 & 23 & 14 & 35 \\
\hline C18:3 (ALA) & - & - & - & 34 & 68 & 5 & 18 & 34 & 1 \\
\hline C20:4 (ARA) & 4.5 & - & 6 & 3 & 1 & 7 & 7 & - & 12 \\
\hline C22:6 (DHA) & 1 & - & 2 & 1 & - & 3 & - & - & - \\
\hline$\Sigma_{\text {PUFA }}$ & 25.5 & 1 & 51 & 60 & 77 & 51 & 48 & 48 & 48 \\
\hline$n-6 / n-3$ & 24.5 & - & - & 0.7 & - & - & 1.7 & - & - \\
\hline
\end{tabular}

${ }^{a}$ Tabular entries are the average of duplicate determinations from different experimental trials.

${ }^{\mathrm{b}}$ The oil used in the reaction is given in parentheses.

of egg-yolk PC with ALA (Chojnacka et al., 2009), the transesterification of soy lecithin with the methyl esters of linseed oil (Ghosh and Bhattacharyya, 1997) and transacylation of phospholipids with synthetic monolinolenin (Hara et al., 2002). Due to economic reasons it is desirable to look for inexpensive acyl donors for that purpose. Therefore we decided to use linseed oil, a natural source of ALA, as an acyl donor in lipase-catalyzed direct interesterification with PC. The fatty acid composition of linseed oil TAG (Table 1) revealed that it contains almost $60 \%$ of ALA whereas the purity of commercially available ALA is about $70 \%$.

Three commercially available lipases: Lipozyme ${ }^{\circledR}$, Lipozyme TL IM and immobilized Candida antarctica lipase B (Novozym 435) were tested in our studies. Two first enzymes are classified as 1,3-regiospecific lipases (Guo et al., 2005), the third one is classified as non regiospecific lipase but shows high selectivity towards the $s n-1$ position (Virto and Adlecreutz, 2000).

The specificity of these enzymes prevents the transesterification of unsaturated fatty acids at the $s n-2$ position of PC. As a result, only the saturated fatty acids from the $s n-1$ position of PC are exchanged during the interesterification process to the unsaturated fatty acids from the $s n-1$ and $s n-3$ positions of TAGs from plant oils.

Novozym 435 is possibly the most common lipase used as biocatalyst in organic synthesis (Anderson et al., 1998). This immobilized preparation is obtained by the immobilization of lipase B from Candida antarctica via the interfacial activation of the enzyme on a moderately hydrophobic resin, Lewatit VP OC 1600 (Uppenberg et al., 1994).

Lipozyme TL IM also has been used in multiple reactions (Fernandez-Lafuente, 2010). It is an immobilized lipase from Thermomyces lanuginosus produced by a genetically modified strain of Aspergillus oryzae and immobilized on a silicate via ionic adsorption (Peng et al., 2002).

Immobilized lipase from Rhizomисо miehei (RML) has been produced and used mainly in the modification of oils and fats, but it has also been also successfully applied in many reactions in organic chemistry (Rodrigues and Fernandez-Lafuente, 2010). The support of this immobilized enzyme is Duolite ES 562, a weak anion exchange resin based on phenol-formaldehyde copolymers (Huge-Jensen et al., 1987).

All of these lipases are commonly used for the modification of natural acylglycerols (Gunstone, 1999; Lee and Akoh, 1998; Fomuso and Akoh, 1998; Akoh et al., 1995) and synthetic or natural phospholipids (Vikbjerg et al., 2005; Lyberg et al., 2005; Peng et al., 2002; Mutua and Akoh, 1993). They also showed activity in the acidolysis of PC with ALA (Chojnacka et al., 2009), therefore they were chosen as biocatalysts in the present studies.

The conditions applied for the reaction systems in our present investigations were also chosen on the basis of earlier studies (Chojnacka et al., 2009). They were as follows: $20 \%$ lipase dosage (based on the weight of substrates), temperature $55^{\circ} \mathrm{C}$ and hexane as a solvent. The only difference was a lower linseed oil/PC molar ratio (2:1), because the acyl donors (TAGs in linseed oil) contain two acyl chains (at $s n-1$ and $s n-3$ positions) susceptible to enzyme action.

The time course of the incorporation of ALA into PC by lipases is shown in Fig. 1. Among the lipases Novozym 435 exhibited the highest activity giving $34 \%$ incorporation of ALA in $72 \mathrm{~h}$, whereas Lipozyme $^{\circledR}$ afforded $18 \%$ of ALA in modified PC. 


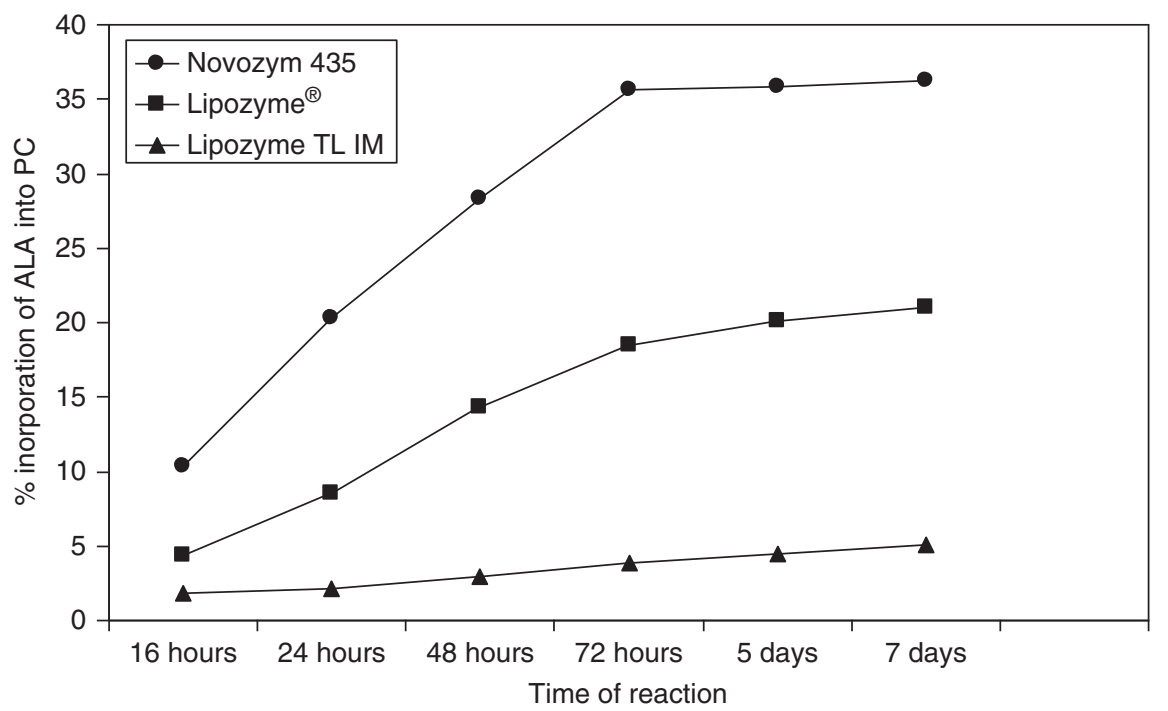

FIGURE 1. Increase (\%) in the $\alpha$-linolenic acid (ALA) content in egg-yolk PC during transesterification with linseed oil catalyzed by three different lipases.

Lipozyme TL IM showed the lowest activity in this process and only $4 \%$ of ALA was detected in the modified PC. When the reaction was continued for more than $72 \mathrm{~h}$ no significant increase in ALA in modified PC was observed and the total yield of PC was reduced due to the formation of lyso-PC. Adlecreutz and co-workers have reported that the loss of PC in the reaction system may occur via hydrolysis, a side-reaction leading to the formation of 2-acyl LPC in the presence of lipase (Adlecreutz et al., 2002). Moreover, hydrolysis also produces glycerophosphatidylcholine (GPC) from 1-acyl LPC (obtained from 2-acyl LPC via acyl migration). In our studies the isolated yield of the structured PC ranged from 35 to $55 \%$.

Similar differences in activity of the enzymes used (Novozym $435>$ Lipozyme $^{\circledR}>$ Lipozyme TL IM) were observed by us earlier during the acidolysis of egg-yolk PC with ALA (Chojnacka et al., 2009). The incorporation of ALA was slightly lower $(28 \%$ in the case of Novozym 435) than that obtained in the interesterification process described here. On the other hand, Ghosh et al. (1997) modified soy lecithin using the methyl esters (ME) of linseed oil $(53.5 \%$ purity) in interesterification catalyzed by immobilized lipase from $M$. miehei with a $1: 5$ molar ratio of substrates (PC:ME). They achieved only $10.2 \%$ of ALA incorporation after 48 hours of reaction increasing its content in PC from 5.2\% to $15.4 \%$. Hara et al. (2002) carried out the transacylation of soy PC with monolinolenin (18:3-MG) and no regiospecific lipase OF originating in Candida rugosa and they reported an increase in ALA in soy PC from 6.3 to $19.9 \%$, after 48 hours of reaction at $37^{\circ} \mathrm{C}$.
Analyzing the total and positional FA composition of the native and modified egg-yolk PC (Table 2) one can see that the increase of ALA was accompanied by a reduction in palmitic (16:0) and stearic acid (18:0). In the case of palmitic acid an approximately 3 -fold decrease in its content was observed whereas the amount of stearic acid was reduced by even 5 -fold. On the other hand, small increases in oleic and linoleic acid (18:2) were noticed as a consequence of the FA composition of linseed oil which contained almost equal $(16 \%)$ amounts of both acids.

The results of the positional analysis show that ALA was introduced mainly in the $s n-1$ position of PC which is in accordance with the 1,3-regiospecificity of the lipases studied.

The result of the reaction of PC with linseed oil was not only the incorporation of ALA into PC but also a reduction in the $n-6 / n-3$ ratio in eggyolk PC from 24.5 to 0.7 in the case of Novozym 435 and to 1.7 in the case of Lipozyme ${ }^{\circledR}$ (Table 2). This feature is very positive in the context of the production of dietary enriched egg-yolk PC as a food supplement because an increase in the dietary intake of $n-6$ PUFA changes the physiological state to a prothrombotic and proinflammatory state (Simopoulos, 2002).

\subsection{Interesterification of egg-yolk $P C$ with plant oils riched in $n-6$ PUFAs}

Four different plant oils were used as $n$-6-PUFAs acyl donors in the transesterification of egg-yolk phosphatidylcholine in order to obtain LA-enriched PC and GLA-enriched PC which are useful in 
cosmetic formulations. The fatty acid compositions of these plant oils are shown in Table 1. Safflower oil and sunflower oil predominantly contain linoleic acid (over $70 \%$ ). Evening primrose oil is the richest source of $n-6$ PUFA, due to the fact that besides the highest amount of LA it also contains a considerable amount of $\gamma$-linolenic acid (GLA, 10.4\%). Borage oil is known as the richest natural source of GLA (20.4\%).

For the incorporation of $n-6$ PUFAs at the $s n-1$ position of egg yolk PC we tried the same reaction system and biocatalysts as for the reaction of PC with linseed oil. All the reactions were carried out for $72 \mathrm{~h}$.

In the transesterification of egg-yolk $\mathrm{PC}$ with TAGs rich in linoleic acid (safflower, sunflower and evening primrose oils), comparable results were obtained (Tables 3 and 4). The maximum incorporation of LA into PC was $46.7 \%$ from an initial content of $20 \%$, using Novozym 435 and evening primrose oil. With safflower and sunflower oils, at the presence of this enzyme linoleic acid was incorporated into egg-yolk PC up to 43.9 and $38.7 \%$, respectively. The percentage incorporation of LA was higher than obtained by Hara et al. (2002) in the transacylation of egg-yolk PC with monolinolein (18:2-MG) in the presence of lipase OF. They reported an increase in the linoleic acid content in modified PC from 7.6 to $28 \%$.

Transesterification between egg-yolk PC and LA-rich oils with Lipozyme TL IM or Lipozyme ${ }^{\circledR}$ as biocatalysts allowed for the production of structured PC with similar linoleic acid contents ranging from 26.5 to $34.3 \%$. Contrary to our previous experimental trials with linseed oil as an acyl donor it was found that Lipozyme TL IM had a slightly better ability to incorporate linoleic acid into PC than $\alpha$-linolenic acid. This phenomenon can be explained by the slight discrimination of very long chain PUFAs by different lipases. Peng et al. (2002) reported that Lipozyme TL IM had a better possibility to incorporate caprylic acid (C8:0) into PLs than EPA and DHA.

TABLE 3. Fatty acid composition (\% according to GC) of egg-yolk PC and structured PC (SPC) obtained after $72 \mathrm{~h}$ of enzymatic transesterification of egg-yolk PC with safflower and sunflower oil ${ }^{\mathrm{a}}$

\begin{tabular}{|c|c|c|c|c|c|c|c|}
\hline \multirow[b]{2}{*}{ FA } & \multirow[b]{2}{*}{ native $\mathrm{PC}$} & \multicolumn{3}{|c|}{ SPC (safflower oil) ${ }^{b}$} & \multicolumn{3}{|c|}{ SPC (sunflower oil) } \\
\hline & & Novozym 435 & Lipozyme ${ }^{\circledR}$ & Lipozyme TL IM & Novozym 435 & Lipozyme ${ }^{\circledR}$ & Lipozyme TL IM \\
\hline C16:0 & 30 & 8.8 & 21.7 & 19.8 & 13.9 & 19.9 & 24.5 \\
\hline C16:1 & 1.5 & - & - & - & - & - & \\
\hline C18:0 & 15 & 5.4 & 11.9 & 13.2 & 8.0 & 12.7 & 14.1 \\
\hline C18:1 & 28 & 39.5 & 32.9 & 33.0 & 35.7 & 31.3 & 30.9 \\
\hline C18:2 & 20 & 43.9 & 28.7 & 28.8 & 38.7 & 27.5 & 26.5 \\
\hline C20:4 & 4.5 & 2.4 & 4.8 & 5.2 & 3.7 & 4.1 & 4.0 \\
\hline$\Sigma_{n-6 \text { PUFA }}$ & 24.5 & 46.3 & 33.5 & 34 & 42.4 & 31.6 & 30.5 \\
\hline
\end{tabular}

${ }^{a}$ Tabular entries are the average of duplicate determinations from different experimental trials.

${ }^{\mathrm{b}}$ The oil used in the reaction is given in parentheses.

TABLE 4. Fatty acid composition (\% according to GC) of egg-yolk PC and structured PC (SPC) obtained after $72 \mathrm{~h}$ of enzymatic transesterification of egg-yolk PC with borage and evening primrose oil ${ }^{\mathrm{a}}$

\begin{tabular}{|c|c|c|c|c|c|c|c|}
\hline \multirow[b]{2}{*}{ FA } & \multirow[b]{2}{*}{ native $\mathrm{PC}$} & \multicolumn{3}{|c|}{ SPC (borage oil) } & \multicolumn{3}{|c|}{ SPC (evening primrose oil) } \\
\hline & & Novozym 435 & Lipozyme ${ }^{\circledR}$ & Lipozyme TL IM & Novozym 435 & Lipozyme ${ }^{\circledR}$ & Lipozyme TL IM \\
\hline $\mathrm{C} 16: 0$ & 30 & 15.7 & 21.9 & 23.4 & 9.4 & 20.0 & 18.9 \\
\hline C16:1 & 1.5 & - & - & - & - & - & \\
\hline C18:0 & 15 & 9.2 & 12.7 & 13.8 & 4.5 & 10.7 & 9.6 \\
\hline C18:1 & 28 & 35.5 & 33.8 & 32.7 & 32.2 & 30.4 & 33.7 \\
\hline C18:2 & 20 & 28.2 & 25.6 & 24.3 & 46.7 & 33.3 & 34.3 \\
\hline C18:3 (GLA) & - & 7.3 & 0.9 & 0.6 & 4.0 & 0.6 & 0.8 \\
\hline C20:4 & 4.5 & 4.1 & 5.1 & 5.2 & 3.2 & 5.0 & 4.0 \\
\hline$\Sigma_{n-6 \text { PUFA }}$ & 24.5 & 39.6 & 31.6 & 30.1 & 53.9 & 38.9 & 39.1 \\
\hline
\end{tabular}

${ }^{a}$ Tabular entries are the average of duplicate determinations from different experimental trials.

${ }^{\mathrm{b}}$ The oil used in the reaction is given in parentheses. 
Our trials to enrich egg-yolk PC in $\gamma$-linolenic acid were not so effective because of the fact that the amount of GLA in borage and evening primrose oils is significantly lower than the amount of ALA and LA in oils used in previous experiments. However, using Novozym 435 turned out to be the most successful and allowed for the incorporation of $7.3 \%$ and $4 \%$ of GLA into PC when borage and evening primrose oils were used as acyl donors, respectively. Lipozyme TL IM and Lipozyme ${ }^{\circledR}$ revealed very low activity in the interesterification of egg-yolk PC and borage oil.

The results of positional analysis of $n-6$ enriched PC (Table 5) showed the incorporation of LA and GLA in the $s n-1$ position, similar to the incorporation of ALA (Table 2).

\section{CONCLUSIONS}

Phosphatidylcholine from egg-yolk was modified successfully by the introduction of the residues of polyunsaturated fatty acids from the $n-3$ and $n-6$ family derived from plant oils. In our studies the modification of PC by immobilized lipase from Candida antarctica (Novozym 435) and linseed oil (source of ALA, $n-3$ PUFA) or evening primrose oil (source of LA and GLA, both $n$-6 PUFAs) gave products with very attractive fatty acid profiles (Fig. 2). The SPC obtained from the transesterification of egg-yolk PC with linseed oil contained 34\% of $n-3$ PUFAs, whereas that obtained with evening primrose oil had over $53 \%$ of $n$-6 PUFAs. In the case of both structured PC the contents of saturated acid did not exceed $14 \%$. Additionally, the modification of PC with linseed oil allowed for the reduction of the $n-6 / n-3$ ratio in egg-yolk PC from 24.5 to 0.7 or 1.7 , using Novozym 435 and Lipozyme ${ }^{\circledR}$, respectively.

The cost of the process is lowered due to replacement of synthetic acyl donors with the cheaper natural plant oils. The optimization of reaction conditions (reaction temperature, enzyme load, water activity, PC/oil molar ratio) is still needed and will

TABLE 5. Positional distribution of LA and GLA ( $\%$ according to GC) in native egg-yolk PC and $n$ - 6 -enriched phosphatidylcholine (n-6-PC) obtained after 72 hours of Novozym 435-catalyzed transesterification of egg-yolk PC with different oils ${ }^{\mathrm{a}}$

\begin{tabular}{|c|c|c|c|c|c|c|c|c|c|c|c|c|c|c|c|}
\hline \multirow[b]{2}{*}{ FA } & \multicolumn{3}{|c|}{ Native egg-yolk PC } & \multicolumn{3}{|c|}{$\begin{array}{c}n-6-\mathrm{PC} \\
\text { (safflower oil) }^{\mathrm{b}}\end{array}$} & \multicolumn{3}{|c|}{$\begin{array}{c}n-6-P C \\
\text { (sunflower oil) }\end{array}$} & \multicolumn{3}{|c|}{$\begin{array}{c}n-6-P C \\
\text { (borage oil) }\end{array}$} & \multicolumn{3}{|c|}{$\begin{array}{c}n-6-\mathrm{PC} \\
\text { (evening primrose oil) }\end{array}$} \\
\hline & Total & $s n-1$ & $s n-2$ & Total & sn-1 & $s n-2$ & Total & $s n-1$ & $s n-2$ & Total & sn-1 & sn-2 & Total & $s n-1$ & $s n-2$ \\
\hline C18:2(LA) & 20 & 1 & 43 & 43.9 & 40.3 & 42.1 & 38.7 & 36 & 43.2 & 28.2 & 25.4 & 43.5 & 46.7 & 46.7 & 41 \\
\hline C18:3 (GLA) & - & - & - & - & - & - & - & - & - & 7.3 & 12 & 1 & 4.0 & 6.6 & 0.8 \\
\hline
\end{tabular}

${ }^{a}$ Tabular entries are the average of duplicate determinations from different experimental trials.

${ }^{\mathrm{b}}$ The oil used in the reaction is given in parentheses.

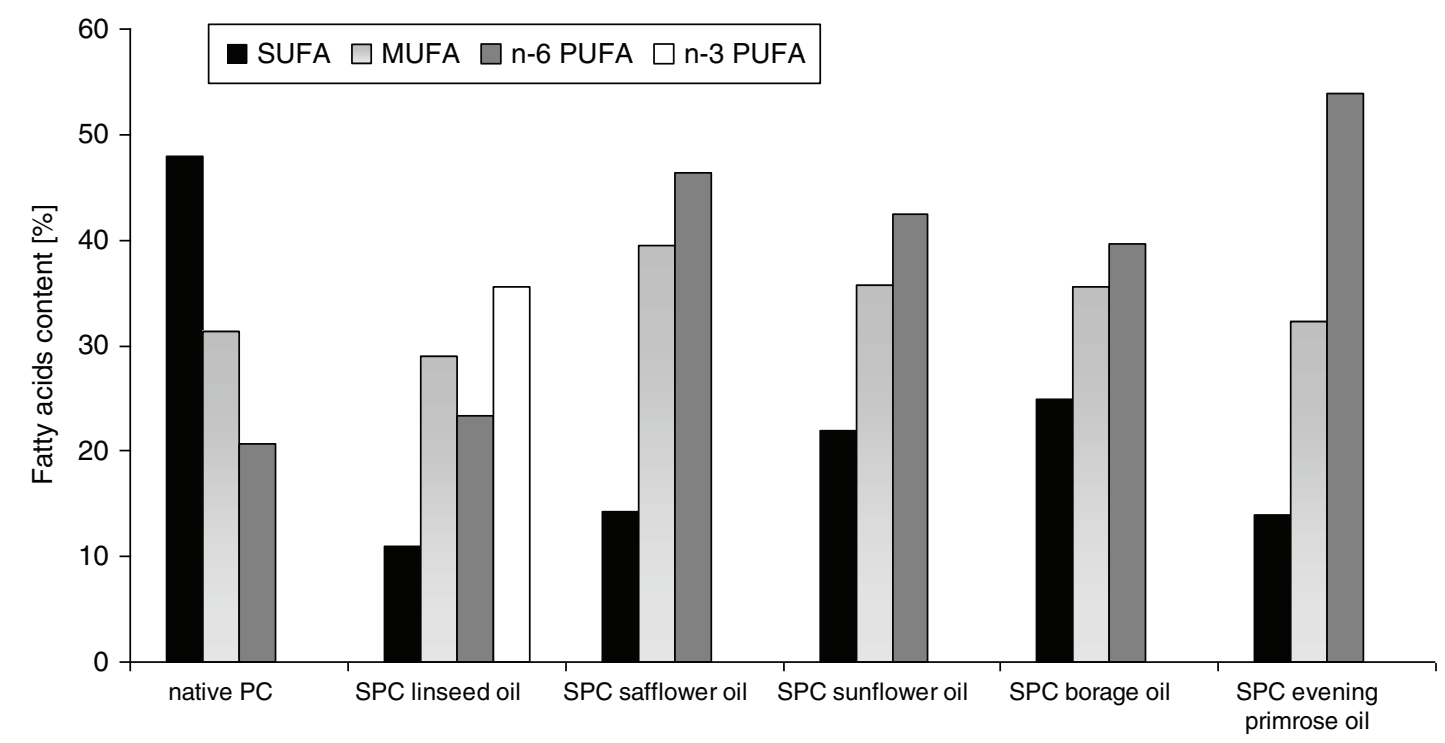

FIGURE 2. Fatty acid profiles of native egg-yolk PC and structured PC (SPC) obtained in the transesterifications with different plant oils after $72 \mathrm{~h}$ of reaction catalyzed by Novozym 435 in hexane. 
be published soon. In addition, the enzyme activity may differ depending on the immobilization form (Rodriguez, 2010) and this aspect may explain the differences in the enzymatic activities observed in our studies.

PUFA-enriched PC is recognized as a multifunctional lipid with two functionalities: PUFAs and PC. It can find applications in the nutraceutical (ALA-PC) or cosmetic (LA-PC and GLA-PC) fields.

\section{AKNOWLEDGMENTS}

This project was financed by National Science Center Project no. 2012/05/B/NZ9/03358.

\section{REFERENCES}

Adlercreutz D, Budde H, Wehtje E. 2002. Synthesis of phosphatidylcholine with defined fatty acid in the sn-1 position by lipase-catalyzed esterification and transesterification reaction. Biotechnol. Bioeng. 78, 403-411. http://dx.doi. org/10.1002/bit.10225.

Akoh CC, Jennings BH, Lillard DA. 1995. Enzymatic modification of trilinolein: Incorporation of $n-3$ polyunsaturated fatty acids. J. Am. Oil Chem. Soc. 72, 1317-1321. http:// dx.doi.org/10.1007/BF02546205.

Anderson EM, Larsson KM, Kirk O. 1998. One BiocatalystMany Applications: The Use of Candida Antarctica B-Lipase in Organic Synthesis. Biocatal. Biotransform. 16, 181-204 http///dx.doi.org/10.3109/10242429809003198.

Aymond WM, Van Elswyk ME. 1995. Yolk thiobarbituric acid reactive substances and $n-3$ fatty acids in response to whole and ground flaxseed. Poult. Sci. 74, 1388-1394. http:// dx.doi.org/10.3382/ps.0741388.

Baeza-Jiménez R, González-Rodríguez J, Kim I-H, García HS, Otero C. 2012. Use of immobilized phospholipase $\mathrm{A}_{1}$-catalyzed acidolysis for the production of structured phosphatidylcholine with an elevated conjugated linoleic acid content. Grasas Aceites 63, 44-52. http://dx.doi. org/10.3989/gya.045211.

Berry EJ, Hirsch J. 1986. Does dietary linolenic acid influence blood pressure? Am. J. Clin. Nutr. 44, 336-340.

Bigger JT, El-Sherif T. 2001. Polyunsaturated fatty acids and cardiovascular events. A fish tale. Circulation. 103, 623625. http://dx.doi.org/10.1161/01.CIR.103.5.623.

Brockerhoff H, Yurkowski M. 1966. Stereospecific analyses of several vegetable fats. J Lipid Res. 7, 62-64.

Chojnacka A, Gładkowski W, Kiełbowicz G, Wawrzeńczyk C. 2009. Enzymatic enrichment of egg-yolk phosphatidylcholine with $\alpha$-linolenic acid. Biotechnol. Lett. 31, 705-709. http://dx.doi.org/10.1007/s10529-009-9915-6

Christie WW, Nikolova-Damyanova B, Laakso P, Herslof B. 1991. Stereospecific analysis of triacyl-sn-glycerols via resolution of diastereomeric diacylglycerol derivatives by HPLC on silica. J. Am. Oil Chem. Soc. 68, 695-701. http:// dx.doi.org/10.1007/BF02662155.

Cobos A, de la Hoz L, Cambero MI, Ordóñez JA. 1995. Dietary modification and hen strain dependence of egg yolk lipids. Food Res. Int. 28, 71-76. http://dx.doi. org/10.1016/0963-9969(95)93333-P.

Dowhan W. 1997. Molecular basis for membrane phospholipid diversity: why are there so many phosholipids? Annu. Rev. Biochem. 66, 199-232. http://dx.doi.org/10.1146/annurev. biochem.66.1.199.

Fernandez-Lafuente R. 2010. Lipase from Thermomyces lanuginosus: Uses and prospects as an industrial biocatalyst. J. Mol. Catal. B: Enzym. 62, 197-212. http://dx.doi. org/10.1016/j.molcatb.2009.11.010.

Fomuso LB, Akoh CC. 1998. Structured lipids: Lipase-catalyzed interesterification of tricaproin and trilinolein. J. Am.
Oil Chem. Soc. 75, 405-410. http://dx.doi.org/10.1007/ s11746-998-0059-y.

Fraeye I, Bruneel C, Lemahieu C, Buyse J, Muylaert K, Foubert I. 2012. Dietary enrichment of eggs with omega-3 fatty acids: A review. Food Res. Int. 48, 961-969. http://dx.doi. org/10.1016/j.foodres.2012.03.014.

Gabizon A, Goren D, Horowitz AT, Tzemach D, Lossos A, Siegal T. 1997. Long-circulating liposomes for drug delivery in cancer therapy: a review of biodistribution in tumorbearing animals. Adv. Drug Deliv. Res. 24, 337-344. http:// dx.doi.org/10.1016/S0169-409X(96)00476-0.

Garcia HS, Kim I-H, Lopez-Hernandez A, Hill Jr. CG. 2008. Enrichment of lecithin with n-3 fatty acids by acidolysis using immobilized phospholipase $\mathrm{A}_{1}$. Grasas Aceites, 59, 368-374. http://dx.doi.org/10.3989/gya.2008.v59.i4.531.

Ghosh M, Bhattacharyya DK. 1997. Soy lecithin - monoester interchange reaction by microbial lipase. J. Am. Oil Chem. Soc. 74, 761-763. http://dx.doi.org/10.1007/ s11746-997-0215-9.

Gładkowski W, Kiełbowicz G, Chojnacka A, Bobak Ł, Spychaj R, Dobrzański Z, Trziszka T, Wawrzeńczyk C. 2014. The effect of feed supplementation with dietary sources of $n-3$ polyunsaturated fatty acids, flaxseed and algae Schizochytrium sp., on their incorporation into lipid fractions of Japanese quail eggs. Int. J. Food Sci. Tech. 49, 1876-1885. http://dx.doi.org/10.1111/ijfs.12497.

Gładkowski W, Chojnacka A, Kiełbowicz G, Trziszka T, Wawrzeńczyk C. 2012. Isolation of pure phospholipid fraction from egg-yolk. J. Am. Oil Chem. Soc. 89, 179-182. http://dx.doi.org/10.1007/s11746-011-1893-x.

Gładkowski W, Kiełbowicz G, Chojnacka A, Gil M, Trziszka T, Dobrzański Z, Wawrzeńczyk C. 2011. Fatty acid composition of egg yolk phospholipid fractions as the effect of feed supplementation of Lohmann Brown hens with humine-fat preparations. Food Chem. 126, 1013-1018. http://dx.doi.org/10.1016/j.foodchem.2010.11.112.

Van Gool CJ, Zeegers MP, Thijs C. 2004. Epidemiology and health services research. Oral essential fatty acids supplementation in atopic dermatitis - a meta-analysis of placebo-controlled trials. Br. J. Dermatol. 150, 728-740. http://dx.doi.org/10.1111/j.0007-0963.2004.05851.x.

Gunstone FD. 1999. Enzymes as biocatalysts in the modification of natural lipids. J. Sci. Food Agric. 79, 1535-1549. http://dx.doi. org/10.1002/(SICI) 1097-0010(199909)79:12<1535::AIDJSFA430>3.0.CO;2-7.

Guo Z, Vikbjerg AF, Xu X. 2005. Enzymatic modification of phospholipids for functional applications and human nutrition. Biotechnol. Adv. 23, 203-259. http://dx.doi. org/10.1016/j.biotechadv.2005.02.001.

Hara S, Hasuo H, Nakasat, M, Higaki Y, Totani Y. 2002. Modification of soybean phospholipids by enzymatic transacylation. J. Oleo Sci. 51, 417-422. http://dx.doi.org/ 10.5650/jos.51.417.

Haraldsson GG, Thorarenson A. 1999. Preparation of phospholipids highly enriched with $n-3$ polyunsaturated fatty acids by lipase. J. Am. Oil. Chem. Soc. 76, 1143-1149. http://dx doi.org/10.1007/s11746-999-0087-2.

Holub DJ, Holub BJ. 2004. Omega-3 fatty acids from fish oils and cardiovascular disease. Mol. Cell. Biochem. 263, 217-225. http://dx.doi.org/10.1023/B:MCBI.0000041863.11248.8d.

Huge-Jensen B, Galluzzo DR, Jensen RG. 1987. Partial purification and characterization of free and immobilized lipases from Mucor miehei. Lipids, 22, 559-565. http://dx.doi. org/10.1007/BF02537281.

Kiełbowicz G, Gładkowski W, Chojnacka A, Wawrzeńczyk C. 2012. A simple method for positional analysis of phosphatidylcholine. Food Chem. 135, 2542-2548. http://dx.doi. org/10.1016/j.foodchem.2012.07.005

Kim I-H, Garcia HS, Hill Jr. CG. 2010. Synthesis of Structured Phosphatidylcholine Containing n-3 PUFA Residues via Acidolysis Mediated by Immobilized Phospholipase A 1 . J. Am. Oil. Chem. Soc. 87, 1293-1299. http://dx.doi. org/10.1007/s11746-010-1609-7.

Kim I-H, Garcia HS, Hill Jr. CG. 2007. Phospholipase $\mathrm{A}_{1}$-catalyzed synthesis of phospholipids enriched in $n-3$ polyunsaturated fatty acid residues. Enzyme 
10 A. Chojnacka, W. Gładkowski, G. Kiełbowicz, A. Gliszczyńska, N. Niezgoda and C. Wawrzeńczyk

Microb. Tech. 40, 1130-1135. http://dx.doi.org/10.1016/j. enzmictec.2006.08.018.

Kris-Etherton PM, Hecker KD, Binkoski AE. 2004 Polyunsaturated fatty acids and cardiovascular health. Nutr. Rev. 62,414 426. http://dx.doi.org/10.1111/j.1753-4887.2004. tb00013.x.

Lee K-T, Akoh CC. 1998. Solvent-free enzymatic synthesis of structured lipids from peanut oil and caprylic acid in a stirred tank batch reactor. J. Am. Oil. Chem. Soc. 75, 15331537. http://dx.doi.org/10.1007/s11746-998-0090-z.

Lewis NM, Seburg S, Flanagan NL. 2000. Enriched eggs as a source of $n-3$ polyunsaturated fatty acids for humans. Poultr. Sc. 79, 971-974. http://dx.doi.org/10.1093/ps/79. 7.971 .

Lyberg A-M, Adlercreutz D, Adlercreutz P. 2005 Enzymatic and chemical synthesis of phosphatidylcholine regioisomers containing eicosapentaenoic acid or docosahexaenoic acid. Eur. J Lipid Sci. Tech. 107, 279-290.

Muggli R. 2005. Systemic evening primrose oil improves the biophysical skin parameters of healthy adults. Int. J. Cosmetic Sci. 27, 243-249. http://dx.doi.org/10.1111/j. 1467-2494.2005.00274.x.

Mutua LN, Akoh CC. 1993. Lipase-catalyzed modification of phospholipids: incorporation of $n-3$ fatty acids into biosurfactants. J. Am. Oil Chem. Soc. 70, 125-128. http:// dx.doi.org/10.1007/BF02542613.

Nagao K, Yanagita T. 2008. Bioactive lipids in metabolic syndrome. Prog. Lipid Res. 47, 127-146. http://dx.doi. org/10.1016/j.plipres.2007.12.002

Palacios LE, Wang T. 2005. Egg-yolk lipid fractionation and lecithin characterization. J. Am. Oil Chem. Soc. 82, 571-578. http://dx.doi.org/10.1007/s11746-005-1110-5.

Park CW, Kwon SJ, Han JJ, Rhee JS. 2000. Transesterification of phosphatidylcholine with eicosapentaenoic acid ethyl ester using phospholipase $\mathrm{A}_{2}$ in organic solvent. Biotechnol. Lett. 22, 147-150. http://dx.doi.org/10.1023/A:1005620707624.
Peng L, Xu X, Mu H, Høy C-E, Adler-Nissen J. 2002. Production of structured phospholipids by lipase-catalyzed acidolysis: optimization using response surface methodology. Enzyme Microb. Technol. 31, 523-532. http://dx.doi.org/10.1016/ S0141-0229(02)00147-3.

Rodrigues RC, Fernandez-Lafuente R. 2010. Lipase from Rhizomucor miehei as an industrial biocatalyst in chemical process. J. Mol. Catal. B: Enzym, 64, 1-22. http://dx.doi. org/10.1016/j.molcatb. 2010.02.003.

Simopoulos AP. 2002. The importance of the ratio of omega-6/ omega-3 essential fatty acids. Biomed. Pharmacother. 56, 365-379. http://dx.doi.org/10.1016/S0753-3322(02) 00253-6.

Schneider M. 2001. Phospholipids for functional food. Eur. J. LipidSci. Tech.104,98-101.http://dx.doi.org/10.1002/14389312(200102)103:2<98::AID-EJLT98>3.3.CO $2-7$.

Uauy RMD, Dangour AD. 2006. Nutrition in Brain Development and Aging: Role of Essential Fatty Acids. Nutr. Rev. 64, 24-33. http://dx.doi.org/10.1111/j.1753-4887.2006. tb00242.x.

Uppenberg J, Patkar S, Bergfors T, Jones TA. 1994. Crystallization and Preliminary X-ray Studies of Lipase B from Candida antarctica. J. Mol. Biol. 235, 790-792. http:// dx.doi.org/10.1006/jmbi.1994.1035.

Vessby B. 2003. Dietary fat, fatty acid composition in plasma and the metabolic syndrome. Curr. Opin. Lipidol. 14,15-19. http://dx.doi.org/10.1097/00041433-200302000-00004.

Vikbjerg AF, Mu H, Xu X. 2005. Parameters affecting incorporation and by-product formation during the production of structured phospholipids by lipase-catalyzed acidolysis in solvent free system. J. Mol. Catal. B 36, 14-21. http:// dx.doi.org/10.1016/j.molcatb.2005.07.002.

Virto C, Adlecreutz P. 2000. Lysophosphatidylcholine synthesis with Candida antarctica lipase B (Novozymes 435). Enzyme Microb. Tech. 26, 630-635. http://dx.doi.org/10.1016/ S0141-0229(00)00147-2. 